\title{
COMPARISON OF AMIKACIN PHARMACOKINETICS IN A KILLER WHALE (ORCINUS ORCA) AND A BELUGA WHALE (DELPHINAPTERUS LEUCAS)
}

\author{
Butch KuKanich, D.V.M., Mark Papich, D.V.M., M.S., Dipl. A.C.V.C.P., David Huff, D.V.M., and \\ Michael Stoskopf, D.V.M., Ph.D., Dipl. A.C.Z.M.
}

\begin{abstract}
Amikacin, an aminoglycoside antimicrobial, was administered to a killer whale (Orcinus orca) and a beluga whale (Delphinapterus leucas) for the treatment of clinical signs consistent with gram-negative aerobic bacterial infections. Dosage regimens were designed to target a maximal plasma concentration 8-10 times the minimum inhibitory concentrations of the pathogen and to reduce the risk of aminoglycoside toxicity. Allometric analysis of published pharmacokinetic parameters in mature animals yielded a relationship for amikacin's volume of distribution, in milliliters, given by the equation $\mathrm{Vd}=151.058(\mathrm{BW})^{1.043}$. An initial dose for amikacin was estimated by calculating the volume of distribution and targeted maximal concentration. With this information, dosage regimens for i.m. administration were designed for a killer whale and a beluga whale. Therapeutic drug monitoring was performed on each whale to assess the individual pharmacokinetic parameters. The elimination half-life $(5.99 \mathrm{hr})$, volume of distribution per bioavailability $(319 \mathrm{ml} / \mathrm{kg})$, and clearance per bioavailability $(0.61 \mathrm{ml} / \mathrm{min} / \mathrm{kg})$ were calculated for the killer whale. The elimination half-life $(5.03 \mathrm{hr})$, volume of distribution per bioavailability $(229 \mathrm{ml} / \mathrm{kg})$, and clearance per bioavailability $(0.53 \mathrm{ml} /$ $\mathrm{min} / \mathrm{kg}$ ) were calculated for the beluga whale. The volume of distribution predicted from the allometric equation for both whales was similar to the calculated pharmacokinetic parameter. Both whales exhibited a prolonged elimination half-life and decreased clearance when compared with other animal species despite normal renal parameters on biochemistry panels. Allometric principles and therapeutic drug monitoring were used to accurately determine the doses in these cases and to avoid toxicity.
\end{abstract}

Key words: Aminoglycoside, amikacin, Delphinapterus leucas, pharmacokinetics, whale, Orcinus orca.

\section{INTRODUCTION}

Amikacin is a semisynthetic aminoglycoside antimicrobial with a broad spectrum of activity including gram-positive and gram-negative aerobic bacteria, Pseudomonas spp., and members of the Enterobacteriaceae. Amikacin's primary site of action is the $30 \mathrm{~S}$ ribosomal subunit. The aminoglycosides' bactericidal activity is concentration dependent: the higher the concentration, the higher the rate of bacterial death. Aminoglycosides also exhibit a concentration-dependent postantibiotic effect (PAE): continued bacterial death even when the concentration is below the minimal inhibitory concentration (MIC) of the pathogen. ${ }^{8}$ The PAE allows effective antimicrobial protocols to be implemented with extended intervals of dosing. In human medicine, this has evolved into the widely ac-

From Department of Molecular Biomedical Sciences, College of Veterinary Medicine, North Carolina State University, 4700 Hillsborough Street, Raleigh, North Carolina 27606, USA (KuKanich, Papich); the Vancouver Aquarium Marine Science Centre, 845 Avison Way, Vancouver, British Columbia V6B3X8, Canada (Huff); and the Department of Clinical Sciences, College of Veterinary Medicine, North Carolina State University, 4700 Hillsborough Street, Raleigh, North Carolina 27606, USA (Stoskopf). Correspondence should be directed to Dr. KuKanich. cepted extended-interval aminoglycoside dosing (EIAD) used in most hospitals. ${ }^{13}$ The duration of the PAE in vivo has been demonstrated to be as long as $15.2 \mathrm{hr}$ after treatment with amikacin. ${ }^{8}$ The most common adverse effects of aminoglycosides include nephrotoxicity, ototoxicity, and neuromuscular blockade. ${ }^{6}$ Accumulation of aminoglycosides in the renal tubular cells by pinocytosis produces renal tubular injury. ${ }^{1}$ The EIAD also has the advantage of reducing exposure to the drug concentrations that may induce renal toxicosis. ${ }^{20}$

Amikacin has the broadest spectrum of activity of the aminoglycosides because of its enhanced resistance to aminoglycoside-inactivating enzymes. It has virtually no oral absorption but has bioavailability greater than $90 \%$ after extravascular parenteral administration in most species (Table 1).

Aminoglycosides are polar, basic molecules with a volume of distribution limited to extracellular fluids, and eliminated primarily by glomerular filtration. ${ }^{6}$ These properties have allowed accurate estimation of gentamicin dose recommendations across mammalian species using the principles of allometry. ${ }^{14}$ That is, body composition of extracellular fluid is consistent among mammals and can be predicted from interspecies scaling. ${ }^{14,19}$ Gentamicin renal clearance and plasma elimination half-life have also been predicted from allometric relationships. ${ }^{14,19}$ When these principles were applied to the 
Table 1. Comparative GFR and selected amikacin pharmacokinetic parameters for various species. Note the similarities between the glomerular filtration rates and amikacin clearance. ${ }^{\mathrm{a}}$

\begin{tabular}{lccccr}
\hline \multicolumn{1}{c}{ Species } & $\begin{array}{c}\mathrm{GFR} \\
(\mathrm{ml} / \mathrm{min} / \mathrm{kg})\end{array}$ & $\begin{array}{c}\mathrm{Cl}_{\mathrm{T}} \\
(\mathrm{ml} / \mathrm{min} / \mathrm{kg})\end{array}$ & $\begin{array}{c}\mathrm{t}_{1 / 2} \\
(\mathrm{hr})\end{array}$ & $\begin{array}{c}\mathrm{Vd} \\
(\mathrm{ml} / \mathrm{kg})\end{array}$ & $\begin{array}{c}\mathrm{F} \\
(\%)\end{array}$ \\
\hline Humans $^{6,7,17}$ & 1.37 & 1.3 & 2.3 & 270 & 98 \\
Cats $^{10,11}$ & 2.72 & 1.46 & 1.30 & 170 & 95 \\
Dogs $^{5,12}$ & 3.97 & 4.00 & 0.85 & 223 & $>90$ \\
Goats $^{4,21}$ & 2.26 & 2.16 & 1.41 & 263 & 102 \\
Horses $^{15,18}$ & 1.83 & 1.49 & 1.44 & 198 & 95 \\
Beluga whale & & $0.53^{\mathrm{b}}$ & 5.03 & $229^{\mathrm{b}}$ & \\
Killer whale & & $0.61^{\mathrm{b}}$ & 5.99 & $319^{\mathrm{b}}$ & \\
\hline
\end{tabular}

${ }^{a}$ GFR, glomerular filtration rate; $\mathrm{Cl}_{\mathrm{T}}$, total body clearance of amikacin; $\mathrm{t}_{1 / 2}$, elimination half-life; Vd, volume of distribution at steady state; F, bioavailability after intramuscular administration.

${ }^{\mathrm{b}}$ Corrected for bioavailability.

$\mathbf{A}$

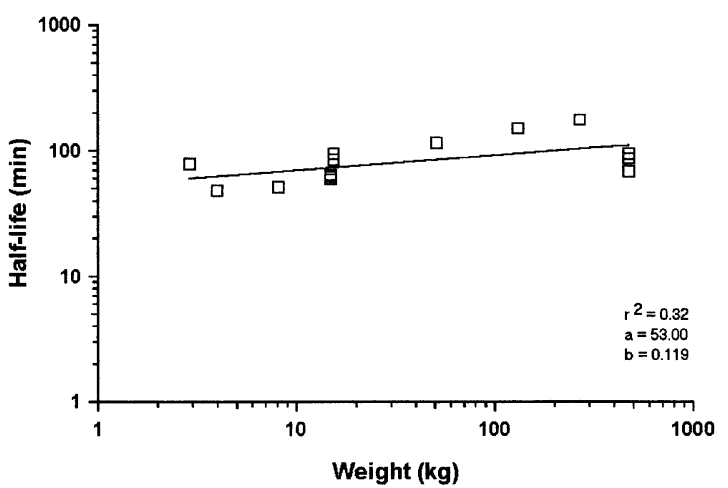

B

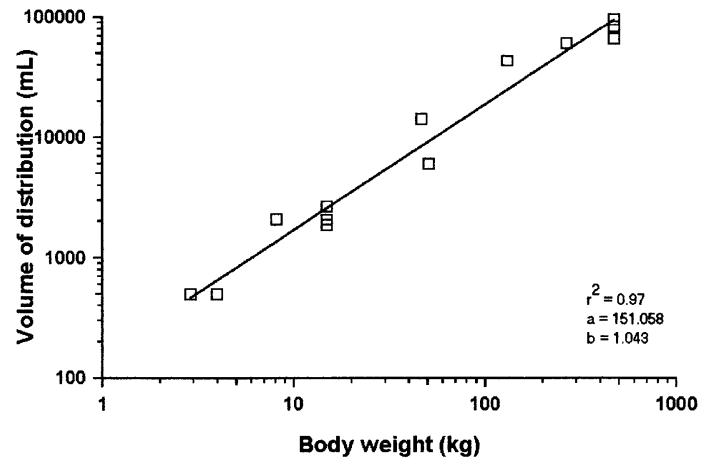

Figure 1. Panel A: Log-log allometric plot of amikacin elimination half-life (hr) and body weight $(\mathrm{kg})$ for various animals for which pharmacokinetic data are available. Panel B: Log-log allometric plot of amikacin volume of distribution $(\mathrm{ml})$ and body weight $(\mathrm{kg})$ for various animals for which intravenous pharmacokinetic data are available. elimination half-life of amikacin, there was not a strong allometric relationship (Fig. 1). However, allometric analysis of amikacin's volume of distribution in adult animals revealed a relationship with the equation:

$$
\mathrm{Vd}=\mathrm{a}(\mathrm{BW})^{\mathrm{b}}
$$

where Vd is the volume of distribution (area method), in milliliters, a is the allometric coefficient, b is the allometric exponent, and BW is the body weight of the animal in kilograms. Linear regression on a $\log -\log$ scale of pharmacokinetic data available from other species yielded the values: a $=151.058, \mathrm{~b}=1.043$, with a coefficient of determination $\left(r^{2}\right) 0.97$ (Fig. 2). This relationship is particularly useful for amikacin because it allows initial dosages to be calculated from the pharmacokinetic relationship:

$$
\text { Dose }=(\mathrm{Vd}) \times(\mathrm{C})
$$

where Vd is the volume of distribution (area), and $\mathrm{C}$ is the targeted drug concentration. This equation ordinarily is applied regardless of the route of ad-

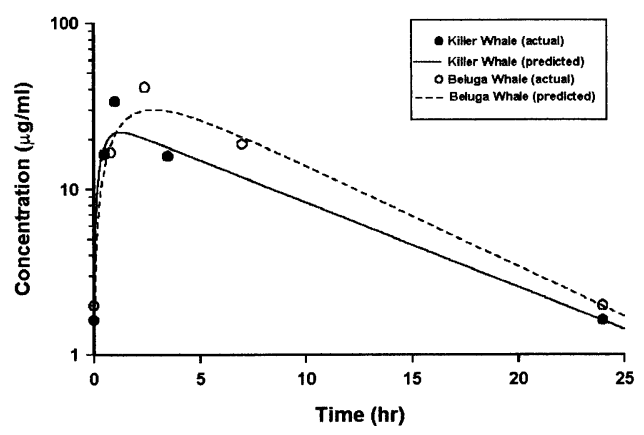

Figure 2. Semilogarithmic plot of plasma concentration versus time for i.m. amikacin $(10 \mathrm{mg} / \mathrm{kg})$ in a killer whale and i.m. amikacin $(12 \mathrm{mg} / \mathrm{kg})$ in a beluga whale. 
ministration because i.m. administration produces rapid absorption, and high bioavailability ( $>90 \%)$ is expected in most mammals. However, we hypothesized that bioavailability from i.m. injection in whales may be less compared with other mammals due to leakage of drug through the needle tract because cetacean skin is relatively nonelastic. Equation 2 allowed us to derive an initial dose, but an estimation of the dosing interval required a determination of the elimination half-life, which can be prolonged in certain animals.

To maximize efficacy of aminoglycosides, we sought a maximum plasma concentration $\left(\mathrm{C}_{\mathrm{MAX}}\right)$ at least $8-10$ times the MIC of the pathogen. ${ }^{16}$ To minimize nephrotoxicity, the dosage regimen also should produce low trough plasma concentrations. Recommended trough ranges for amikacin in humans are between $<1$ and $<7 \mu \mathrm{g} / \mathrm{ml}$. However, no controlled studies have compared toxicity from various regimens or among species. ${ }^{2,3}$ The amikacin MICs of the most common bacterial pathogens encountered at the North Carolina State University Veterinary Teaching Hospital (NCSU-VTH) are 1$4 \mu \mathrm{g} / \mathrm{ml}$. Therefore, the Clinical Pharmacology Service at the NCSU-VTH uses a target peak concentration of $40 \mu \mathrm{g} / \mathrm{ml}$ for dosage adjustments. These two cases of whales monitored at NCSU-VTH illustrate the use of therapeutic drug monitoring and allometric scaling for amikacin dosage determination.

\section{CASE REPORTS}

\section{Case 1}

A 23-yr-old, 2,400-kg female killer whale (Orcinus orca) became lethargic and anorectic. Diagnostic blood panels showed neutrophilia, increased fibrinogen levels, and an elevated erythrocyte sedimentation rate, consistent with an inflammatory condition. Allometric analysis calculated the volume of distribution to be $211 \mathrm{ml} / \mathrm{kg}$, using Equation 1. To achieve targeted plasma concentrations of 40 $\mu \mathrm{g} / \mathrm{ml}$, the calculated dosage was $8.5 \mathrm{mg} / \mathrm{kg}$ using Equation 2. However, because a bioavailability for i.m. amikacin in cetaceans is unknown, a conservative estimate of $85 \%$ yielded a corrected dosage of $10 \mathrm{mg} / \mathrm{kg}$, using Equation 3 .

$$
\text { Corrected dose }=\text { dose } \div \text { bioavailability }
$$

Treatment was initiated with amikacin (AmiglydeV, Fort Dodge, Fort Dodge, Iowa 50501, USA; 10 $\mathrm{mg} / \mathrm{kg}$ ) administered i.m. in the epaxial muscles with a $15.25-\mathrm{cm}$ needle every $24 \mathrm{hr}$. Ceftazidime (Fortaz, Glaxo Wellcome, Research Triangle Park, North Carolina 27709, USA; $20 \mathrm{mg} / \mathrm{kg}$, i.m.) was
Table 2. Pharmacokinetic parameters calculated from a killer whale dosed $10 \mathrm{mg} / \mathrm{kg}$ i.m., q $24 \mathrm{hr}$, and a beluga whale dosed $12 \mathrm{mg} / \mathrm{kg}$ i.m., q $24 \mathrm{hr}^{\mathrm{a}}$

\begin{tabular}{lrr}
\hline \multicolumn{1}{c}{ Variable } & $\begin{array}{c}\text { Killer } \\
\text { whale }\end{array}$ & $\begin{array}{c}\text { Beluga } \\
\text { whale }\end{array}$ \\
\hline$\lambda_{\mathrm{z}}(1 / \mathrm{hr})$ & 0.12 & 0.14 \\
$\mathrm{t}_{1 / 2} \lambda_{\mathrm{z}}(\mathrm{hr})$ & 5.99 & 5.03 \\
$\mathrm{MRT}(\mathrm{hr})$ & 5.70 & 6.78 \\
$\mathrm{Cl}_{\mathrm{T}} / \mathrm{F}(\mathrm{ml} / \mathrm{min} / \mathrm{kg})$ & 0.61 & 0.53 \\
$\mathrm{Vd}_{\text {area }} / \mathrm{F}(\mathrm{ml} / \mathrm{kg})$ & 318.61 & 228.63 \\
$\mathrm{AUC}_{0-\infty}(\mathrm{hr} \times \mathrm{ug} / \mathrm{ml})$ & 271.39 & 380.82 \\
$\mathrm{AUMC}_{0-\infty}(\mathrm{hr} \times \mathrm{hr} \times \mu \mathrm{g} / \mathrm{ml})$ & 1546.68 & 2589.56 \\
$\mathrm{C}_{\max }(\mu \mathrm{g} / \mathrm{ml})$ & 33.64 & 41.09 \\
$\mathrm{~T}_{\max }(\mathrm{hr})$ & 1.00 & 2.42 \\
\hline
\end{tabular}

${ }^{a} \lambda_{z}$, first-order rate constant; $t_{1 / 2} \lambda_{z}$, half-life of the terminal portion of the curve; MRT, mean residence time; $\mathrm{Cl}_{\mathrm{T}}$, total body clearance per bioavailability; $\mathrm{Vd}_{\text {area }} / \mathrm{F}$, volume of distribution of the area during the elimination phase per bioavailability; $\mathrm{AUC}_{0-\infty}$, area under the curve from 0 to infinity; $\mathrm{AUMC}_{0-\infty}$, area under the first moment curve from 0 to infinity; $\mathrm{C}_{\max }$, maximum concentration; $\mathrm{T}_{\max }$, time to maximal concentration.

also administered every $24 \mathrm{hr}$, for which concentrations also were monitored at the NCSU-VTH Clinical Pharmacology Service. Three days after treatment was initiated, blood samples for amikacin plasma analysis were obtained before i.m. administration (time 0) at 0.5 and $1 \mathrm{hr}$ and at $3.5 \mathrm{hr}$ after injection for amikacin pharmacokinetic analysis. A fifth time point was extrapolated to $24 \mathrm{hr}$ using the time 0 sample. Plasma was separated within $1 \mathrm{hr}$ of obtaining the sample and stored refrigerated for $48 \mathrm{hr}$ until analysis was completed. Plasma amikacin concentrations were determined using fluorescence polarization immunoassay (TDx, Abbott laboratories, Abbott Park, Illinois 60064, USA). Compartmental (one compartment with an absorption phase) and noncompartmental analyses were performed with a commercially available pharmacokinetics program and are presented in Table 2 (WinNonLin 4.01, Pharsight, Mountain View, California 94040, USA). The plasma profile for the compartmental model is presented in Figure 2, which estimates both the absorption and elimination phases.

The elimination half-life was $5.99 \mathrm{hr}$, clearance (per bioavailability) was $0.61 \mathrm{ml} / \mathrm{min} / \mathrm{kg}$, and the volume of distribution (per bioavailability) was 319 $\mathrm{ml} / \mathrm{kg}$. The maximal plasma concentration was $33.66 \mu \mathrm{g} / \mathrm{ml}$, lower than our targeted concentration of $40 \mu \mathrm{g} / \mathrm{ml}$. A new dose of $13 \mathrm{mg} / \mathrm{kg}$ i.m. was recommended to achieve the targeted plasma concentration using Equation 2 and the calculated volume of distribution (area). The trough concentration, $1.62 \mu \mathrm{g} / \mathrm{ml}$, was within the recommended 
trough range ( $<1$ to $<7 \mu \mathrm{g} / \mathrm{ml}$ ); however, extending the dosing interval was recommended if prolonged treatment was planned. Because the peak concentration was lower than our prediction based on the dose calculated from the allometric equation and $\mathrm{Vd}$, we hypothesized that the lower than expected concentration was caused by a lower bioavailability than the $85 \%$ we initially assumed. Intramuscular bioavailability of $65 \%$ would explain the difference between our predicted peak concentration and the actual concentration $(8.5 \mathrm{mg} / \mathrm{kg} / 0.65=13 \mathrm{mg} / \mathrm{kg})$.

\section{Case 2}

A 6-yr-old, 550-kg female beluga whale (Delphinapterus leucas) developed lethargy and anorexia. Results of a diagnostic blood panel revealed neutrophilia, elevated fibrinogen, and an elevated erythrocyte sedimentation rate, indicative of active inflammation. Physical examination revealed no abnormalities. Allometric analysis yielded a volume of distribution of $198 \mathrm{ml} / \mathrm{kg}$ using Equation 1 . Equation 2 predicted the dose to achieve a plasma concentration of $40 \mu \mathrm{g} / \mathrm{ml}$ to be $8 \mathrm{mg} / \mathrm{kg}$. We assumed a $65 \%$ bioavailability from i.m. injection based on our experience in case 1 . Therefore, in the beluga whale, we adjusted the recommended dosage to $12 \mathrm{mg} / \mathrm{kg}$ using Equation 3. Therapy was initiated with amikacin $(12 \mathrm{mg} / \mathrm{kg}$, i.m. with a $15.25-\mathrm{cm}$ needle in the epaxial musculature every $24 \mathrm{hr}$ ), clindamycin (Antirobe, Pharmacia \& Upjohn, Kalamazoo, Michigan 49001, USA; 7.5 mg/ kg, p.o., b.i.d. in fish), and itraconazole (Sporanox, Janssen Pharmaceutica, Titusville, New Jersey 08560, USA; $2.5 \mathrm{mg} / \mathrm{kg}$ p.o., b.i.d in fish). Four serial plasma samples were obtained 7 days after the initiation of treatment to assess the individual pharmacokinetics of amikacin. Blood samples were obtained just before i.m. injection, 0.8 and $2.42 \mathrm{hr}$, and $7 \mathrm{hr}$ after injection. A fifth time point was extrapolated to $24 \mathrm{hr}$, using the presample value. The samples were handled and analyzed as in case 1 . In addition, protein binding was assessed to ensure that it was not contributing to the increased elimination half-life.

The plasma profile for the compartmental model is presented in Figure 2. The elimination half-life was $5.3 \mathrm{hr}$, the clearance (per bioavailability) 0.53 $\mathrm{ml} / \mathrm{min} / \mathrm{kg}$, and volume of distribution (per bioavailability) $229 \mathrm{ml} / \mathrm{kg}$ (Table 2). The protein binding, as determined by a 30,000-molecular weight micropartition device (Centrifree, Millipore Corporation, Bedford, Massachusetts 01730, USA), was $11 \pm 3 \%$. The maximal concentration of amikacin, $41.09 \mu \mathrm{g} / \mathrm{ml}$, was very close to the targeted value of $40 \mu \mathrm{g} / \mathrm{ml}$. The trough concentration, 1.99 $\mu \mathrm{g} / \mathrm{ml}$, was within the recommended trough range $(<1$ to $<7 \mu \mathrm{g} / \mathrm{ml})$; however, extending the dosing interval was recommended if prolonged treatment was planned.

\section{DISCUSSION}

We identified a lower systemic clearance (0.61 and $0.53 \mathrm{ml} / \mathrm{kg} / \mathrm{min}$ ) for amikacin in these whales than would be predicted from allometric principles. The low clearance rate resulted in longer than expected half-lives (5.99 and $5.03 \mathrm{hr}$ ), but the volume of distribution was within the value predicted from allometric analysis. ${ }^{19}$ The horse, a terrestrial mammal similar in size to the beluga whale, has a clearance of $1.49 \mathrm{ml} / \mathrm{min} / \mathrm{kg}$ and a half-life of $1.44 \mathrm{hr}$ (Table 1 ). ${ }^{18}$ Amikacin is primarily cleared by glomerular filtration, with clearance rates among species that correspond to glomerular filtration rates (GFR; Table 1). The decreased systemic clearance of amikacin exhibited in the killer and beluga whales may be attributed to a low normal GFR, physiologic changes due to the primary disease process, or alterations caused by previous diseases. ${ }^{19}$ There is no evidence that the concurrent drugs administered in these cases affect aminoglycoside pharmacokinetics. A literature search revealed no information on the GFR of healthy cetaceans. However, the GFR of another marine mammal, the elephant seal (Mirounga angustirostris), has been shown to be as low as $0.49 \mathrm{ml} / \mathrm{kg} / \mathrm{min}$ in midlactation females and $1.03 \mathrm{ml} / \mathrm{kg} / \mathrm{min}$ in late-lactation females. ${ }^{9}$ Glomerular excretion of a drug is also dependent on protein binding of the drug. ${ }^{19}$ The protein binding in the beluga was only $11 \%$, which does not account for the decreased clearance. Chemistry parameters, including blood urea nitrogen, creatinine, and uric acid, were monitored throughout the course of treatment and remained within normal limits.

The uncertainty of the reason(s) for the decreased clearance and prolonged half-life present in the killer and beluga whales and the potential toxicities of aminoglycoside antimicrobials warrant further investigation. Examining the GFR or pharmacokinetics (or both) of amikacin in healthy killer and beluga whales could differentiate between individual and interspecies variations in the clearance of the drug.

The initial dose estimates for both whales were $65 \%$ lower than the calculated dose. The low estimate of the dose could be attributed to low bioavailability, leakage of the drug through the injection tract, injection into the blubber layer, or slow absorption. Our initial estimate of the dose for the killer whale was low because Equation 2 does not 
include an adjustment for bioavailability less than $100 \%$. Interindividual and intraindividual variabilities are also possible, which affect predicted plasma concentrations.

\section{CONCLUSIONS}

These cases illustrate the use of therapeutic drug monitoring to make accurate dose adjustments after the initiation of treatment. Therapeutic drug monitoring is not only used to avoid toxicity but also to assure therapeutic success by achieving appropriate plasma concentrations. Therapeutic drug monitoring can be performed with a few samples (only four were used in these cases), with flexible timing of sampling, and can provide valuable information to make accurate dosage recommendations, which will maximize effectiveness and minimize adverse effects. Analysis of amikacin in plasma is available in most hospitals and diagnostic laboratories. These cases also demonstrate the usefulness of allometric scaling for making initial dosing estimates, especially in species where few data are available on the pharmacokinetics of a drug. Allometric analysis of amikacin's volume of distribution allowed initial estimates for doses for which no previous data are available. However, it also showed that in whales, allometric scaling may not be accurate for predicting the half-life for a drug such as amikacin eliminated via the renal system.

Acknowledgments: We thank North Carolina State University, Vancouver Marine Sciences Centre, and Tara Geiger for support and technical assistance.

\section{LITERATURE CITED}

1. Arnoff, G. R., S. T. Pottratz, M. E. Brier, N. E. Walker, N. S. Fineburg, M. D. Glant, and F. C. Luft. 1983. Aminoglycoside accumulation kinetics in rat renal parenchyma. Antimicrob. Agents Chemother. 23: 74-78.

2. Bartal, C., A. Danon, F. Schlaeffer, K. Reisenberg, M. Alkan, R. Smoliakov, A. Sidi, and Y. Almog. 2003. Pharmacokinetic dosing of aminoglycosides: a controlled trial. Am. J. Med. 114: 194-198.

3. Begg, E. J., and M. L. Barclay. 1995. Aminoglycosides 50 years and beyond. Br. J. Clin. Pharmacol. 39: 597-603.

4. Brown, S. A., C. Groves, J. A. Barsanti, and D. R. Finco. 1990. Determination of excretion of inulin, creatinine, sodium sulfanilate, and phenolsulfonphthalein to assess renal function in goats. Am. J. Vet. Res. 51: 581586.

5. Cabana, B. E., and J. G. Taggart. 1973. Comparative pharmacokinetics of BB-K8 and kanamycin in dogs and humans. Antimicrob. Agents Chemother. 3: 478-483.

6. Chambers, H. F., and M. A. Sande. 1996a. Antimicrobial agents: The aminoglycosides. In: Hardman, J. G., and L. E. Limbird (eds.). Goodman \& Gilman's The Pharmacological Basis of Therapeutics, 9th ed. McGraw-Hill, New York, New York. Pp. 1103-1121.

7. Chambers, H. F., and M. A. Sande. 1996b. Pharmacokinetic data. In: Hardman, J. G., and L. E. Limbird (eds.). Goodman \& Gilman's The Pharmacological Basis of Therapeutics, 9th ed. McGraw-Hill, New York, New York. Pp. 1924-2023.

8. Craig, W. A., J. Redington, and S. C. Ebert. 1991. Pharmacodynamics of amikacin in vitro and in mouse thigh and lung infections. J. Antimicrob. Chemother. 27(Suppl. C): 29-40.

9. Crocker, D. E., P. M. Webb, D. P. Costa, and B. J. Le Boeuf. 1998. Protein catabolism and renal function in lactating northern elephant seals. Physiol. Zool. 71: 485491.

10. Haller, M., K. Rohner, W. Muller, F. Reutter, H. Binder, W. Estelberger, and P. Arnold. 2003. Single-injection inulin clearance for routine measurement of glomerular filtration rate in cats. J. Feline Med. Surg. 5: 175181 .

11. Jernigan, A. D., R. C. Wilson, and R. C. Hatch. 1988. Pharmacokinetics of amikacin in cats. Am. J. Vet. Res. 49: 355-358.

12. Kampa, N., I. Bostrom, P. Lord, U. Wennstrom, P. Ohagen, and E. Maripuu. 2003. Day-to-day variability in glomerular filtration rate in normal dogs by scintigraphic technique. J. Vet. Med. A. 50: 37-41.

13. Maglio, D., C. H. Nightingale, and D. P. Nicolau. 2002. Extended interval aminoglycoside dosing: from concept to clinic. Int. J. Antimicrob. Agents 19: 341-348.

14. Martin-Jimenez, T., and J. E. Riviere. 2001. Mixed effects modeling of the disposition of gentamicin across domestic animal species. J. Vet. Pharmacol. Ther. 24: 321-332.

15. Matthews, H. K., F. M. Andrews, G. B. Daniel, W. R. Jacobs, and J. P. Held. 1992. Comparison of standard and radionuclide methods for measurement of glomerular filtration rate and effective renal blood flow in female horses. Am. J. Vet. Res. 53: 1612-1616.

16. Moore, R. D., C. R. Smith, and P. S. Lietman. 1984. Association of aminoglycoside levels with therapeutic outcome in gram-negative pneumonia. Am. J. Med. 100: 352-357.

17. Orlando, R., M. Floreani, R. Padrini, and P. Palatini. 1998. Determination of inulin clearance by bolus intravenous injection in healthy subjects and ascitic patients: equivalence of systemic and renal clearances as glomerular filtration markers. Br. J. Clin. Pharmacol. 46: 605609.

18. Orsini, J. A., L. R. Soma, J. E. Rourke, and M. Park. 1985. Pharmacokinetics of amikacin in the horse following intravenous and intramuscular administration. J. Vet. Pharmacol. Ther. 8: 194-201.

19. Riviere, J. E. 1999. Interspecies extrapolations. In: Riviere, J. E. (ed.). Comparative Pharmacokinetics Principles, Techniques, and Applications. Iowa State Univ. Press, Ames, Iowa. Pp. 296-307.

20. Rybak, M. J., B. J. Abate, S. L. Kang, K. J. Ruff- 
ing, S. A. Lerner, and G. L. Drusano. 1999. Prospective evaluation of the effect of an aminoglycoside dosing regimen on rates of observed nephrotoxicity and ototoxicity. Antimicrob. Agents Chemother. 43: 1549-1555.

21. Uppal, R. P., S. P. Verma, V. Verma, and S. K. Garg.
1997. Comparative pharmacokinetics of amikacin following a single intramuscular or subcutaneous administration in goats (Capra hircus). Vet. Res. 28: 565-570.

Received for publication 27 August 2003 